Original Contribution

\title{
EFFECT OF RUMANOL ML VEGETABLE OIL ON PRODUCTIVITY OF BROILER CHICKENS. I. GROWTH PERFORMANCE
}

\author{
M. Lalev ${ }^{1}$, M. Oblakova ${ }^{1}$, S. Ribarski ${ }^{2}$, P. Hristakieva ${ }^{1}$, N. Mincheva ${ }^{1}$, I. Ivanova ${ }^{1}$ \\ ${ }^{1}$ Agriculture Institute, Stara Zagora, Bulgaria \\ ${ }^{2}$ Trakia University, Stara Zagora, Bulgaria
}

\begin{abstract}
The experiment was conducted between September and October 2014 in the Experimental Base of the Agriculture Institute - Stara Zagora with 150 male Ross 500 chickens divided into two groups: experimental and control. The sunflower oil in the ration of the experimental group was replaced by the feeding oil Rumanol ML. The latter was produced by the German company Rubelmann and includes five vegetable oils - coco, palm, shea, rape and sunflower at different proportions, with total linoleic value between 23-25\%. The following parameters were determined: individual live weight at hatching and at 10,21,35, 49 days of age. At the end of the trial, slaughter analysis of 3 male broiler chickens with body weight close to the group average was made, and after 12-hour fasting 12 slaughter traits were determined. During all periods of growth and development, live body weight was statistically significantly higher in broilers whose diet was supplemented with Rumanol ML ( $<<$ 0.001 ). The addition of feeding oil Rumanol to poultry ration resulted in lower feed consumption per 1 $\mathrm{kg}$ weight gain by $6.8 \%$ and higher European Poultry efficiency factor than controls - by $18.16 \%$. Absolute values of slaughter traits in 35-day-old broiler chickens were statistically significantly different $(\mathrm{p}<0.01)$. At 49 days of age, thigh and breast muscles, as well as grill weight of Rumanolsupplemented birds were by $20.7 \%, 15.5 \%, 11.41 \%$ respectively higher than controls,.
\end{abstract}

Key words: broiler, growth, way of breeding, slaughter analysis, feed oil, vegetable oils

\section{INTRODUCTION}

Fat is the most concentrated source of energy. From all animal species, broiler chickens and turkey poults need metabolisable energy at the highest extent and therefore, of highest level of dietary fat supplementation. The younger the chickens, the more high quality fat should they receive. The addition of fats in poultry rations reduces the transition rate of nutrients through the gastrointestinal tract allowing for a better utilization of nutrients from feeds (1).

In chickens over 4 weeks of age, the saturated to unsaturated fat ratio could be reduced from $1: 2$ during the starter period to $1:(1.4-1.5)$ during the finisher period. The indiscriminate inclusion of fats in diets of unknown composition and content for a given category of birds could have a negative impact on growth (2)

A number of studies proved that the different dietary sources of fat in poultry feeds influence their growth performance, meat quality and feed expenditure $(3,4)$.
Different vegetable oils and fats as raw material from the food industry are the most commonly used energy sources in poultry nutrition (5). The increasing competition for vegetable oils requires using economically profitable alternatives of dietary fats for poultry feeds.

The most conventional vegetable oil, used in Bulgarian livestock husbandry, is sunflower oil. Standard sunflower oil has on the average $11 \%$ saturated fatty acids, palmitic (16:0) and stearic (18: 0) acids, 20\% oleic acid (18: 1), and 69\% linoleic acid (18: 2). This composition as well as the ratio between linoleic/oleic acid is highly variable and depends on a number of factors: the hybrid, growing conditions, storage conditions, technology of sunflower oil production etc.

Historically, men consume a diet with $\omega-6$ : $\omega$ 3 ratio from $1: 1$ to $4: 1(6,7,8)$. Nevertheless, the typical ratios in developed countries at present are over 10: 1 . The main sources of $\mathrm{N}$ 6 PUFA are vegetable oils as corn and soybean 
oils, while sources of $\omega-3$ PUFA are salmon, trout, tuna and plant sources as flaxseed (9). In the recent years in the market offers mixed oils. Generally for them can be said that are mixtures of fatty acids of mono-, di- and triglycerides, in a different amount of obtained entirely from vegetable oils. The arguments are directed to heir exceptional stability against an oxidation and to their high energy value. Another advantage is their availability for feed in contrast to other crude oils, which are used to produce other products. Rumanol ML is the oil with medium Linoleic oil value- $20-25 \%$. This product is a mix with the participation of coconut, palm- core, rapeseed, palm and sunflower oil and acids. The distribution of fatty acids in the product is the following: $28 \%$ saturated amino acids, $43 \%$ monounsaturated amino acids, and polyunsaturated $28 \%$.

Several researchers have investigated the effect of different animal and vegetable oils on the fatty acid content of poultry meat. The lipid content of chicken meat could be modified through supplementation of linoleic (LA) and linolenic (LNA) acids, vegetable oils, fish meal $(10,3)$

The amount of polyunsaturated fatty acids (PUFA) increases after their addition to the diet as long-chain $\omega-3$ FA [eicosapentaenoic acid (EPA), docosapentaenoic acid (DPA) and docosahexaenoic acid (DHA) (11).

The ratio of broiler chickens was supplemented with four levels of dietary polyunsaturated fatty acids (PUFA) $(15,34,45$, and $61 \mathrm{~g} / \mathrm{kg})$ and 4 dietary levels of $\alpha$ - tocopheryl acetate $(\alpha-$ TA) $(0,100,200$, and $400 \mathrm{mg} / \mathrm{kg})$, to evaluate the change of FA amount and type deposited in raw and cooked chicken tissues. The amount of FA of thigh and breast muscles was not influenced by the dietary $\alpha$-TA supplementation. The total FA content of breast meat was $<15 \%$ of the total FA content of thigh meat. Regardless of that, the total PUFA content was increased (12).

The aim of the present study was to establish the effects of feed oil Rumanol ML in poultry feeds on productivity of broiler chickens and physicochemical qualities of meat. For this purpose, we have performed:

1) a comparative study on growth performance until 49 days of age and

2) slaughter analysis of the carcass.

\section{MATERIALS AND METHODS}

The experiment was conducted between September and October 2014 in the Experimental Base of the Agriculture Institute - Stara Zagora with 150 male Ross 500 chickens divided into two groups: experimental and control. The sunflower oil in the ration of the experimental group was replaced by the feeding oil Rumanol ML. The latter was produced by the German company Rubelmann and includes five vegetable oils coco, palm, shea, rape and sunflower at different proportions, with total linoleic value between $23-25 \%$. It has total energy $32.2 \mathrm{~kJ} / \mathrm{g}$ and metabolic energy $38.9-37,8 \mathrm{~kJ} / \mathrm{g}$.

The broilers were housed in boxes, in groups of 25 , at a density of $7 / \mathrm{m}^{2}$, on deep permanent litter, fed ad libitum with constant access to fresh water as per the adopted technology.

During the experiment was applied 3-phase feeding - starter (days 1-10), grower (days 1128), finisher (days 29-49). The feed expenditure was measured on a daily basis for each period, and total for the entire experiment. Mortality rates and the health status were monitored on a daily basis. The following parameters were determined: individual live weight - at hatching and at 10 , $21,35,49$ days of age with technical balance, precision of $1 \mathrm{~g}$.

At the 35 and 49 days of the trial, slaughter analysis of 3 male broiler chickens with body weight close to the group average was made, after 12-hour fasting. Were determined 12 slaughter traits. They served for calculation of the slaughter yield and body parts proportions. Samples from thigh and breast muscles were collected for physico-chemical analysis.

For integral assessment of broiler combinations, the European Poultry efficiency factor (EPEF) was calculated according to the formula:

$\mathrm{EPEF}=\frac{\text { Live body weight }(\mathrm{kg}) \times \text { livability }(\%) \times 100}{\text { fattening period (days) } \times \text { feed intake per } 1 \mathrm{~kg} \text { weight gain }}$

The composition and nutritional value of compound feeds are presented in Table 1 (13).

Data were statistically processed $\mathrm{e}$ by ANOVA/MANOVA and LSD post hoc test using Statistica 8 software (StatSoft, 2009). 
Table 1. Percentage composition of experimental control diet

\begin{tabular}{|l|l|l|l|}
\hline Components & Starter & Grower & Finisher \\
\hline Wheat & 53.86 & 59.08 & 65.25 \\
Soybean oil meal & 28 & 22 & 16 \\
Soybean oil meal & 5 & 5 & 5 \\
Methionine & 0.12 & 0.13 & 0.1 \\
Optizim & 0.1 & 0.1 & 0.1 \\
Salgard & 0.2 & 0.2 & 0.2 \\
Lysine-98\% & 0.18 & 0.3 & 0.3 \\
Salt & 0.25 & 0.25 & 0.25 \\
Limestone & 0.8 & 0.73 & 0.71 \\
Dicalcium & 1.8 & 1.52 & 1.4 \\
phosphate & 0.5 & 0.5 & 0.5 \\
Vitamin trace & & & \\
mineral premix- & 6 & 7 & 7 \\
starter & 0.14 & 0.14 & 0.14 \\
Rumanol/sunflower & 3.000 & 3.000 & 3.000 \\
oil & & & \\
Threonine & & & \\
Fish meal & & & \\
\hline
\end{tabular}

Table 2. Nutritional facts of the compound feed

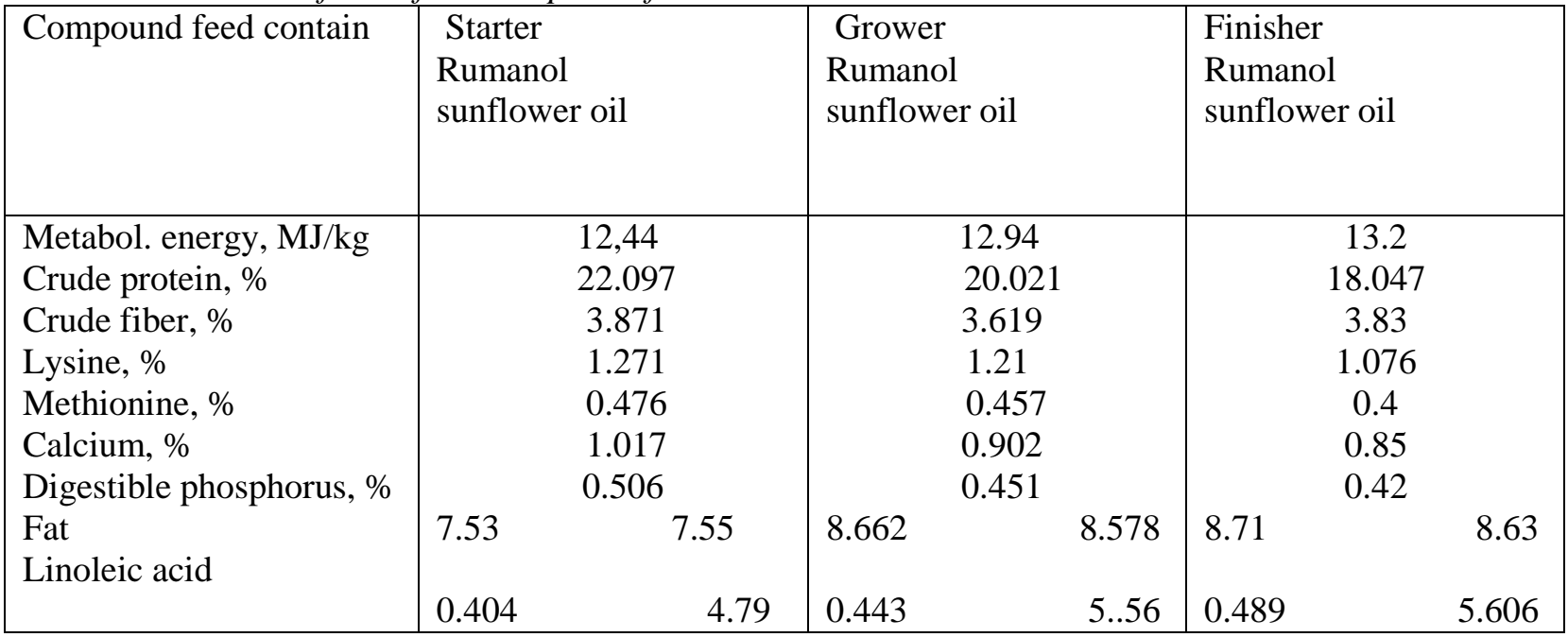

\section{RESULTS AND DISCUSSION}

Table 3 presents the live weight of broilers from both groups during the different age periods. The weight of hatched day-old chicks was uniform and both groups received compound feeds according to their needs for the respective period. The metabolisable energy of diets in the experimental and control groups was comparable - $2977 \mathrm{kcal} / \mathrm{kg}, 3095$ $\mathrm{kcal} / \mathrm{kg}$ and $3154 \mathrm{kcal} / \mathrm{kg}$ for starter, grower and finisher, respectively; and crude protein levels: 22.097, 20.021, and 18.047 (13). The difference was only the presence of feeding oil Rumanol ML in the ration of the experimental group.

The growth performance of experimental chickens during the first period (1-10 day) was by on average $13.94 \mathrm{~g}$ higher, a tendency for a higher growth rate although insignificant. During the next period (10-21 day), experimental chickens exhibited a weight gain of $750.15 \mathrm{~g}$ vs $700.20 \mathrm{~g}$ in controls group. Thus, the supplemented group was superior vs the control by $63.43 \mathrm{~g}$. On day 35 , the tendency was preserved and former group was by $204 \mathrm{~g}$ heavier whereas by the $49^{\text {th }}$ day - by $326.67 \mathrm{~g}$, with statistically significant differences $(\mathrm{p}<0.001)$.

During all growth and development periods, the live weight in supplemented birds was higher evidencing a statistically significant effect of dietary Rumanol ML ( $p<0.001)$.

Feed expenditures during the entire fattening period are shown in Table 4. The feed consumption in experimental chickens has increased by $192.90 \mathrm{~g}$, i.e. by $2.8 \%$ more than in controls, but feed conversion ratio (Table 5) was higher in controls by $141 \mathrm{~g}$. The addition of the feeding oil Rumanol to the diet resulted 
in lower expenditure of feed per $1 \mathrm{~kg}$ weight gain in experimental birds (by 6.8\%).

The European poultry efficiency factor (EPEF) was calculated with regard to the more objective assessment of studied groups of broiler chickens. This parameter gives an idea for the level of utilisation of the genetic potential of birds. The EPEF data (Table 6) showed higher values in supplemented birds, whose economic efficiency was by $18.16 \%$ higher as compared to controls.

Broilers fed Rumanol ML had a higher slaughter yield than controls $-76.4 \%$ vs $74 \%$. Absolute values of studied slaughter traits at 35 days of age were significantly different between groups $(\mathrm{p}<0.01)$ (Table 7). Grill weights were $94.4 \%$ and $93.3 \%$ of the carcass in experimental and controls birds respectively. Thighs of supplemented broiler chickens were by $21.5 \%$ heavier, while breast weight - by $15 \%$ higher than controls.

Table 3. Dynamics of live body weight $(g)$

\begin{tabular}{|l|l|l|l|l|l|}
\hline Groups & 1 day & 10 days & 21 days & 35 days & 49 days \\
\hline Control & $45.85 \pm 0.44$ & $262.82 \pm 11.82$ & $963.02 \pm 47.37$ & $1976.66 \pm 36.66$ & $3066.66 \pm 33.33$ \\
\hline Experimental & $45.36 \pm 0.64$ & $276.30 \pm 9.62$ & $1026.45 \pm 4.16$ & $2180 \pm 30.55^{* * *}$ & $3393.33 \pm 56.66^{* * *}$ \\
\hline
\end{tabular}

Differences significant at $* * * \mathrm{p}<0.001$,

Table 4. Cumulative feed consumption per capita for the period $(\mathrm{g})$

\begin{tabular}{|l|l|l|l|l|}
\hline Groups & $1-10$ days & $11-21$ days & $22-35$ days & $35-49$ days \\
\hline C & 364.5 & 1207.9 & 3522.4 & 6301.9 \\
\hline O & 362.2 & 12361.1 & 3780.1 & 6494.8 \\
\hline
\end{tabular}

Table 5. Feed conversion $(g)$

\begin{tabular}{|l|c|c|c|c|}
\hline Groups & $1-10$ days & $11-21$ days & $22-35$ days & $35-49$ days \\
\hline C & 1387 & 1583 & 1782 & 2055 \\
\hline O & 1311 & 1526 & 1734 & 1914 \\
\hline
\end{tabular}

Table 6. European Poultry efficiency factor

\begin{tabular}{|l|l|l|l|lc|}
\hline Group & $\begin{array}{l}\text { live weight at } 49 \\
\text { days, } \mathrm{kg}\end{array}$ & Livability, \% & $\begin{array}{l}\text { Feed conversion } \\
(\mathrm{kg} / \mathrm{kg})\end{array}$ & \multicolumn{2}{|c|}{ EPEF } \\
absolute & relative \\
\hline $\mathrm{C}$ & $3066.66 \pm 33.33$ & 97.33 & 2.055 & 296.47 & 81.84 \\
\hline $\mathrm{O}$ & $3393.33 \pm 56.66$ & 100 & 1.914 & 361.81 & 100 \\
\hline
\end{tabular}

Table 7. Slaughter analysis at 35 days of age

\begin{tabular}{|c|c|c|c|c|c|}
\hline \multirow[t]{2}{*}{ Traits(g) } & \multirow[t]{2}{*}{ control group } & \multirow[t]{2}{*}{$\begin{array}{l}\text { experimental } \\
\text { group }\end{array}$} & \multirow{2}{*}{$\begin{array}{l}\% \text { superiority of } \\
\text { experimental vs } \\
\text { control group }\end{array}$} & \multicolumn{2}{|c|}{$\begin{array}{c}\% \text { of body parts } \\
\text { vs grill }\end{array}$} \\
\hline & & & & & $\mathrm{O}$ \\
\hline live weight & $1976.667 \pm 36.66$ & $2180 \pm 30.55^{*}$ & 9.93 & & \\
\hline carcass weight & $1462.33 \pm 42.11$ & $1664.32 \pm 8.76^{*}$ & 12.1 & 74 & 76.4 \\
\hline grill & $1372.33 \pm 51.17$ & $1570.99 \pm 9.56^{*}$ & 12.6 & 93.3 & 94.4 \\
\hline breast weight & $449 \pm 26.72$ & $528.33 \pm 5.45^{* *}$ & 15 & 30.7 & 33.7 \\
\hline thighs & $411.33 \pm 10.34$ & $524.33 \pm 9.54 * *$ & 21.5 & 30 & 33.4 \\
\hline wings & $152 \pm 4$ & $151 \pm 4.04$ & 0.6 & 11.1 & 9.7 \\
\hline gizzard & $26.66 \pm 0.88$ & $28.66 \pm 4.40$ & 6.97 & 1.94 & 1.82 \\
\hline liver & $54.66 \pm 1.76$ & $55.33 \pm 2.18$ & 1.21 & 3.98 & 3.52 \\
\hline heart & $13.33 \pm 1.45$ & $9.33 \pm 1.76$ & 30.00 & 0.97 & 0.59 \\
\hline neck & $63.66 \pm 3.66$ & $52.33 \pm 1.76$ & 17.79 & 4.64 & 2.33 \\
\hline edible offal & $90 \pm 1.73$ & $93.33 \pm 4.33$ & 3.5 & 6.6 & 6 \\
\hline rib cage & $360 \pm 5.92$ & $367.33 \pm 10.72$ & 2 & 26.3 & 23.4 \\
\hline abdominal fat & & & & & \\
\hline
\end{tabular}

Differences significant at $* * p<0.01, * p<0.05$ 
Table 8. Slaughter analysis at 49 days of age

\begin{tabular}{|l|l|l|l|lc|}
\hline Traits (g) & control group & experimental group & $\begin{array}{l}\text { \% superiority of } \\
\text { experimental vs } \\
\text { control group }\end{array}$ & \multicolumn{2}{|c|}{$\begin{array}{l}\text { of body parts } \\
\text { vs grill }\end{array}$} \\
\hline live weight & $3066.66 \pm 33.33$ & $3393.33 \pm 56.66^{* *}$ & 9.6 & & O \\
\hline carcass weight & $2313.99 \pm 28.57$ & $2612.31 \pm 108.59^{* *}$ & 11.4 & 75.5 & 77 \\
\hline grill & $2198.99 \pm 38.73$ & $2486 \pm 18.15^{* *}$ & 11.5 & 95.1 & 95.2 \\
\hline breast weight & $699.33 \pm 10.98$ & $828 \pm 22.51^{* *}$ & 15.5 & 31.8 & 33.3 \\
\hline thighs & $656.66 \pm 9.93$ & $750.66 \pm 41.38$ & 20.7 & 29.9 & 30.2 \\
\hline wings & $243 \pm 4.58$ & $253 \pm 11.67$ & 3.9 & 11.1 & 10.2 \\
\hline gizzard & $35.33 \pm 3.92$ & $30.33 \pm 2.18$ & 14.15 & 1.61 & 1.22 \\
\hline liver & $68.66 \pm 1.20$ & $70.33 \pm 2.90$ & 2.37 & 3.12 & 2.83 \\
\hline heart & $15.33 \pm 2.60$ & $15 \pm 1.15$ & 2.15 & 0.69 & 0.60 \\
\hline neck & $49 \pm 3.05$ & $51 \pm 4.35$ & 3.92 & 2.23 & 2.05 \\
\hline edible offal & $115 \pm 7$ & $119.33 \pm 7.26$ & 3.6 & 5.3 & 4.8 \\
\hline rib cage & $577.5 \pm 13.5$ & $632.66 \pm 44.47$ & 8.37 & 26.3 & 25.5 \\
\hline abdominal fat & $22.5 \pm 12.5$ & $28.66 \pm 7.75$ & & & \\
\hline
\end{tabular}

Differences significant at, $* * p<0.01, * p<0.05$

\section{CONCLUSIONS}

1. During all periods of growth and development, live body weight was statistically significantly higher in broilers whose diet was supplemented with Rumanol ML ( $\mathrm{p}<0.001$ ).

2. The addition of feeding oil Rumanol to poultry ration resulted in lower feed consumption per $1 \mathrm{~kg}$ weight gain by $6.8 \%$, and higher European Poultry efficiency factor than controls - by $18.16 \%$.

3. Absolute values of slaughter traits in 35 day-old broiler chickens were statistically significantly different $(p<0.01)$. At 49 days of age, thigh and breast muscles, as well as grill weight of Rumanol-supplemented birds were by $20.7 \%, 15.5 \%, 11.41 \%$ respectively higher than controls.

\section{REFERENCES}

1. Latshaw, J. D., Daily energy intake of broiler chickens is altered by proximate nutrient content and form of the diet. Poult. Sci., 87:89-95, 2008.

2. Stoimenov B., Belorechkov, D., Tsvetanov, M., Beremski, Ch., Bachev, N., Alexandrov, M., Gyurov, B., Manual of Poultry Husbandry, 1997. .Bg

3. Hulan, H.W., Proudfoot, F. G. and Nash, D. M., The effects of different dietary fat sources on general performance and carcass fatty acid composition of broiler chickens.

Poult. Sci. 63:324-332, 1984.

4. Viveros, A., Ortiz, L. T., Rodriguez, M. L., Rebole, A., Alzueta, C., Arija, I., Centeno, C. and Brenes A., Interaction of dietary high-oleic acid sunflower hulls and different fat sources in broiler chickens. Poult. Sci. 88:141-151, 2009.

5. Cherian, G., Metabolic and cardiovascular diseases in poultry: Role of dietary lipids.

Poult. Sci. 86:1012- 1016, 2007.
6. Eaton, S.B., Konner, M. J. and Shostak M., An evolutionary perspective enhances understanding of human nutritional requirements. J. Nutr. 126:1732-1740, 1996.

7. Simopoulos, A. P., Omega-3 fatty acids in the preventionmangement of cardiovascular disease. Can. J. Physiol. Pharmacol. 75:234-239, 1997.

8. Simopoulos, A. P., Evolutionary aspects of diet, the omega-6/ omega-3 ratio and genetic variation: Nutritional implications for chronic diseases. Biomed. Pharmacother. 60:502-507, 2006.

9. Schmitz, G. and Ecker J., The opposing effects of n-3 and n-6 fatty acids. Prog. Lipid Res. 47:147-155, 2008.

10.Lopez-Ferrer, S., Baucells, M. D., Barroeta, A. C. and. Grashorn, M. A., Influence of vegetable oil sources on quality parameters of broiler meat. Archiv. Geflug. 63:291999a.

11.Lopez-Ferrer, S., Baucells, M. D., Barroeta, A. C. and Grashorn, M. A., n-3 Enrichment of Chicken Meat. Use of Very Long-Chain Fatty Acids in Chicken Diets and Their Influence on Meat Quality: Fish Oil, Poultry Science 80:741-752, 2001.

12.Cortinas, L., Villaverde, C., Galobart, J., Baucells, M. D., Codony, R. and Barroeta, A. C. Fatty Acid Content in Chicken Thigh and Breast as Affected by Dietary Polyunsaturation Level, Poultry Science 83:1155-1164, 2004

13.AOAC. Official Methods of Analyses (16th Ed.). Association of Official Analytical Chemists, VA. 1996. 